"Interactive relationship between China's industrial structure and human resources employment structure"

\begin{tabular}{ll} 
AUTHORS & $\begin{array}{l}\text { Lijuan Cui (i) } \\
\text { Viktoriia Medvid (i) } \\
\text { ARTICLE INFO }\end{array}$ \\
\hline Lijuan Cui and Viktoriia Medvid (2022). Interactive relationship between China's \\
industrial structure and human resources employment structure. Problems and \\
Perspectives in Management, 20(1), 177-189. doi:10.21511/ppm.20(1).2022.16
\end{tabular}

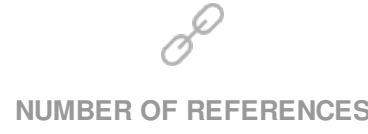

59

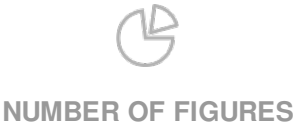

5
E=-

NUMBER OF TABLES

2

(C) The author(s) 2022. This publication is an open access article. 


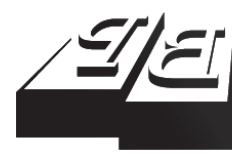

BUSINESS PERSPECTIVES

O

LLC "CPC "Business Perspectives"

Hryhorii Skovoroda lane, 10,

Sumy, 40022, Ukraine

www.businessperspectives.org

Received on: $18^{\text {th }}$ of November, 2021

Accepted on: $20^{\text {th }}$ of January, 2022

Published on: $4^{\text {th }}$ of February, 2022

๑ Lijuan Cui, Viktoriia Medvid, 2022

Lijuan Cui, Ph.D., Associate Professor Department of Management, Faculty of Economics and Management, Sumy National Agrarian University, Ukraine; Henan Institute of Science and Technology, China.

Viktoriia Medvid, Doctor of Economics, Professor, Department of Economics and Entrepreneurship, Faculty of Economics and Management, Sumy National Agrarian University, Ukraine. (Corresponding author)

\section{INTERACTIVE RELATIONSHIP BETWEEN CHINA'S INDUSTRIAL STRUCTURE AND HUMAN RESOURCES EMPLOYMENT STRUCTURE}

\begin{abstract}
This study aims to understand the relationship between China's industrial structure and human resources employment structure. This paper reviewed the relevant data from the China Statistical Yearbook, China Population and Employment Statistical Yearbook between 2010 and 2019 and quantitatively analyzed the interrelationship between the two using the CORREL function, employment elasticity coefficient, and employment structure deviation coefficient. Results indicate that the two have a strong correlation, but the coordination is poor; from the perspective of stimulating economic effect on employment, the total employment elasticity coefficient of the three industries is primarily positive, but the absolute value is close to 0 . The synchronous inspiring effect of economic growth of various industries on employment is not apparent. In terms of equilibrium, the degree of structural deviation of the primary industry fluctuated between -0.70 and -0.75 each year, and the degree of structural deviation of the secondary industry has always hovered around 0.4. Although the degree of structural deviation of the tertiary industry was stable overall, mainly in some years, the deviation coefficient was still higher than 0.2 , and the degree of imbalance between the economic development of various industries and the employment structure is more severe.
\end{abstract}

\section{Keywords \\ China, rural human resources, employment structure, industrial structure, deviation}

\section{JEL Classification J21, E23, M54}

\section{INTRODUCTION}

Relevant theories and the practice of economic development in various countries prove that industry is the carrier of employment, and the development of industry and the employed population are inseparably linked (Zhou et al., 2018). Along with the promotion of urbanization and the implementation of a rural revitalization strategy in China, China's industrial structure has been continuously adjusted, and the problem of labor force employment is more prominent. Can the development of the industrial economy promote employment? Can the increase of the labor force optimize the industrial structure? Does the degree of development of the two match? This series of questions has attracted the interest of scholars, and there are more and more studies on such a relationship (Chen, 2007; Zhou et al., 2018). Reviewing the existing literature, it was found that these studies are primarily micro studies, which focus on analyzing the industrial structural change and employment structure adjustment in a particular region, and less from a national perspective. Therefore, this study analyzes the changes in China's industrial economy and the employment of the labor force from 2010 to 2019, expecting to find out the changes in the relationship between industrial structure and employment structure. 


\section{LITERATURE REVIEW}

As early as the $17^{\text {th }}$ century, the British economist William (2010) in his investigations of the Netherlands and England first discovered that income differences between industries could induce labor to move to sectors with higher incomes. Later, British economist Clark (1940) pointed out that labor employment in the industrial sector increased with a country's GDP per capita, and the tertiary sector could be the main direction of labor attraction because of its higher elasticity. This discovery was called the "Allotment-Clark Theorem". After that, scholars from various countries have studied the adjustment of industrial structure and the change of employment structure from various perspectives such as theoretical construction (Kuznets, 1980; Ranis \& Fei, 1961), impact (Wu, 2016), policy (Xu, 2014), and relationship (Huang et al., 2018).

The Petty-Clark theorem is considered the most important theoretical basis for studying the industrial structure and labor transfer. In addition, Ranis and Fei (1961) established the Ranis-Fei model based on the Lewis dual-sector theory. The model points out that it is necessary to promote the coordinated and balanced development between the industrial and agriculture sectors to transform the economic structure. It also believes that developing countries should focus on developing capital-saving and labor-intensive industries to absorb more labor force. U.S. economist Kuznets (1980) has studied changes in various industries and labor force output value based on Clark's research results. Kuznets (1980) pointed out that the changes in the output value structure of various industries and the changes in the employment structure are not entirely consistent, and the changes in the employment structure often lag behind the changes in the industrial structure. However, the two changes are consistent in the long run.

It is now widely accepted across countries that technological progress (Cao \& Birchenall, 2013), human capital (Zhou \& Xu, 2008), globalization (Rachwał, 2011), and urbanization (Deng et al., 2008) are the main factors affecting changes in industrial and employment structures. Along with the widespread use of new technologies, industries that still use the original production technology will inevitably suffer losses under the impact of new technologies, and the renewal of industries goes hand in hand with technological progress (Schumpeter, 1911). As technology advances, the space for employment demand is increasingly shrinking, leading to a decline in employment (Zimmermann, 1991). Human capital as one of the influencing factors has also been widely studied. Jin (2010) argues that the basis of industrial structure optimization and upgrading is human capital, and one of the critical factors leading to the increase of unemployment is that human capital does not form an adaptive match with the dynamic adjustment of industrial structure in terms of quantity and quality. This view is confirmed by Krumm and Strotmann (2013) who stated that a highly skilled workforce and technological progress contribute to the growth of regional manufacturing employment. Some scholars have also analyzed the influencing factors from globalization and urbanization. Rachwał (2011) researching Poland's industrial structure found that the transformation of the employment structure manifests Poland's industrial transformation, which is related to the EU's socio-economic changes. Deng et al. (2008) showed that urbanization has a specific driving effect on economic growth, and economic growth, in turn, will promote urbanization.

In terms of policy research, scholars generally tend to propose policy recommendations from the problem. Qin and Fang (2011) found that Chongqing City has the problem of employment structure lagging behind the industrial structure, thus proposing policy recommendations such as changing the economic growth model and accelerating the process of urban-rural integration. Zhang and Wang (2014, pp. 45-53) argue that the level of industrialization, technology, and openness to the outside world are the main factors that cause the imbalance between the industrial and employment structures in China, while the improvement of the level of marketization and urbanization has a positive effect on the coordinated development of both. In addition, reforming the household registration system, increasing investment in human capital, and strengthening vocational training is also policy recommendations put forward by Song and Xu (2015).

Regarding the study of the relationship between the two, a consensus was reached that they are 
significantly correlated (Chen, 2007). Chen (2007) used the C-D production function and the regression analysis method to analyze the correlation between China's industrial structure and employment structure. It was found that the output value of industries is negatively correlated with the employment of the primary industry and positively correlated with the employment of the tertiary industry. In terms of the degree of equilibrium, Chen and Shi (2012) found that there is a significant long-term equilibrium relationship between the output value and the number of employed persons in the tertiary industry. However, Zhou et al. (2018) came up with different findings. They took Jiangning District in Nanjing of China as an example, used the employment elasticity coefficient and employment structure deviation coefficient to analyze the data for the period 2005-2015. The research results show that the absorption capacity of industries to the labor force is gradually weakening. The increase of output value of industries can no longer effectively promote the increase of the labor force, and the unbalanced development of industries and employment is more serious. The trend of changes in China's industrial structure and employment structure in the next seven years was also predicted, arguing that there is only a one-way causal relationship between China's employment size and the value-added output in its three industries (Li et al., 2015b).

In terms of research methods, a quantitative analysis is the most widespread method. Using cointegration theory, Li and Gao (2008) found that there is a cointegration relationship between the value-added of secondary and tertiary industries and the number of employed people, but the contribution to employment is not the same. Dai et al. (2015) took the Yangtze River Delta as the research object and constructed a coordinated development model and the corresponding indicator system. The results showed that the industrial structure had been optimized to a certain extent from 1994 to 2013, but the differences between regions are still significant, and the employment structure is lagging behind the industrial development. $\mathrm{Du}$ (2016) used correspondence analysis methods to empirically analyze the employment structure data of rural residents of different income levels and different regions in Jiangsu Province in 2014. Tang (2019) studied the impact of rural finan- cial development and employment structure on farmers' income growth based on statistics from 2003 to 2017 in Anhui Province and conducted an empirical test using cointegration analysis and Granger causality. Some scholars have also adopted qualitative research methods. Sun and Yao (2011) analyzed the overall industrial and economic development of Jiangsu Province based on the center-periphery theory and concluded that the regional development of Jiangsu Province is not coordinated. Zhang (2014) qualitatively analyzed the relationship between the employment structure and industrial structure of Hengyang in Hunan Province and believed that it is necessary to promote the adjustment and optimization of the employment structure and reallocate labor resources to maintain sustainable and stable economic growth. Zhang (2016) found in a review of numerous domestic and foreign documents that the redistribution of resources is an essential factor in promoting the optimization of industrial structure and the adaptation of employment structure to the industrial structure. The more muscular coordination between the two, the higher the quality of economic development.

In summary, the existing literature focuses on empirical studies in terms of research methodology, but these studies are biased towards regional studies and less on national characteristics. Moreover, the data of these studies are relatively old, and the results obtained no longer match the relationship between the two nowadays. Therefore, this study takes China as an example and analyzes the economic development of each industry and labor force employment as panel data for the period of 2010-2019.

\section{METHODOLOGY}

There are many normative econometric analysis methods for analyzing the relationship between industrial structure and employment structure. Employment elasticity and employment structure deviation are commonly used calculation tools at present. Combined with the output value and employment data of various industries in China from 2010 to 2019, the paper analyzes the dynamic change process of the industrial structure and employment structure. On this basis, the employ- 
ment elasticity coefficient and structural deviation of the primary, secondary and tertiary industries are calculated.

\subsection{Employment elasticity coefficient}

The employment elasticity refers to the employment growth rate ratio to the economic growth rate and represents the percentage change in the number of jobs corresponding to each percentage point change in economic growth. This study used the employment elasticity coefficient to examine whether economic growth has a pulling effect on employment growth.

The formula for calculating the employment elasticity coefficient for the industry is:

$$
E S_{i}=\frac{E_{i} \%}{V_{i} \%}
$$

Among these, $E_{i} \%$ is the growth rate of employment in the $i$-th industry, and $V \%$ is the growth rate of value-added in the $i$-th industry. If the employment elasticity coefficient is greater than 0 , it means that economic growth has an "inhalation effect" on employment growth. If the employment elasticity coefficient is less than 0 , it means that economic growth has a "crowding out effect" on employment growth.

\subsection{Employment structure deviation coefficient}

The so-called employment structure deviation refers to the degree of deviation of employment structure compared with its corresponding industrial structure. This indicator is a good reflection of the coherent relationship between these two structures.

The formula for calculating the deviation coefficient of an industry's employment structure is:

$$
D_{i}=\frac{V_{i}}{E_{i}}-1
$$

Among them, $V / E_{i}$ is the comparative labor productivity of industry $i$.The greater the absolute value of $D_{i}$, the greater the degree of deviation of the employment structure; the closer to 0 , the smaller the degree of deviation.
The research data in this paper was mainly adopted from China Statistical Yearbook, China Rural Statistical Yearbook, China Population, and Employment Statistical Yearbook, thus was authentic and authoritative.

\section{RESULTS}

The leading indicators to measure the relationship between industrial structure and employment structure are the output value of each industry and the number of people employed in each industry. Therefore, the dynamic change of industrial structure mainly refers to the change of output value of each industry, and the dynamic change of employment structure mainly refers to the change of employment number of each industry.

\subsection{Dynamic changes in the industrial structure}

The industrial structure is the allocation of capital, human and material resources of a country or region among various sectors of the national economy and ways they constrain each other. Figure 1 showed the changes in the proportion of output value of each industry to the total output value from 2010 to 2019 , and it can be seen that the three industries show apparent differences, among which the primary industry accounted for the lowest and little change in the ups and downs, basically maintained at about $8 \%$. The secondary industry accounted for a yearly decline, from $46.50 \%$ in 2010 to $39 \%$. The tertiary industry's proportion has increased rapidly and has maintained a steady growth trend. In ten years, it had increased from $44.2 \%$ in 2010 to $53.9 \%$ in 2019.

The contribution rate of economic growth can also reflect the changes in the industrial structure (Figure 2). The contribution rate in the primary sector is the lowest, remaining roughly at $4 \%$. The degree of contribution of the secondary sector to GNP growth is decreasing year by year, from $57.40 \%$ in 2010 to $36.80 \%$ in 2019 . In contrast, the contribution of the tertiary industry to GDP growth is increasing year, from 39\% in 2010 to $59.4 \%$ in 2019 . 


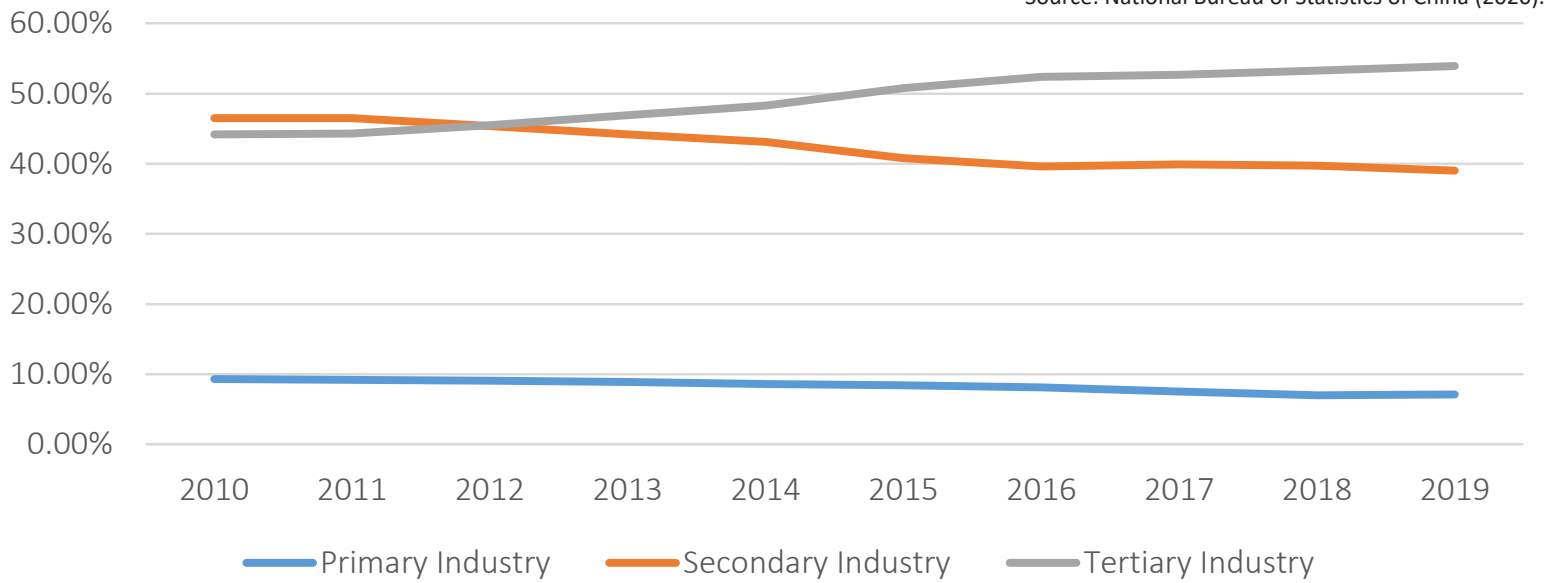

Figure 1. Output value composition of China's three industries (2010-2019)

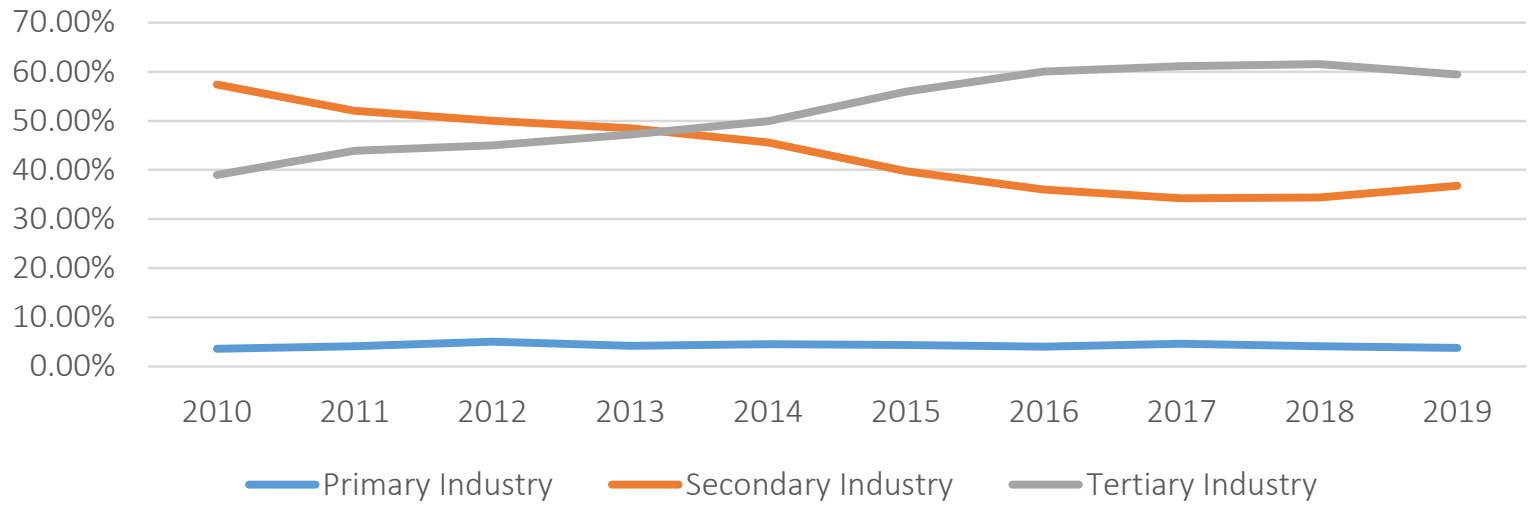

Figure 2. Economic growth contribution rate of China's three industries (2010-2019)

Source: National Bureau of Statistics of China (2020).

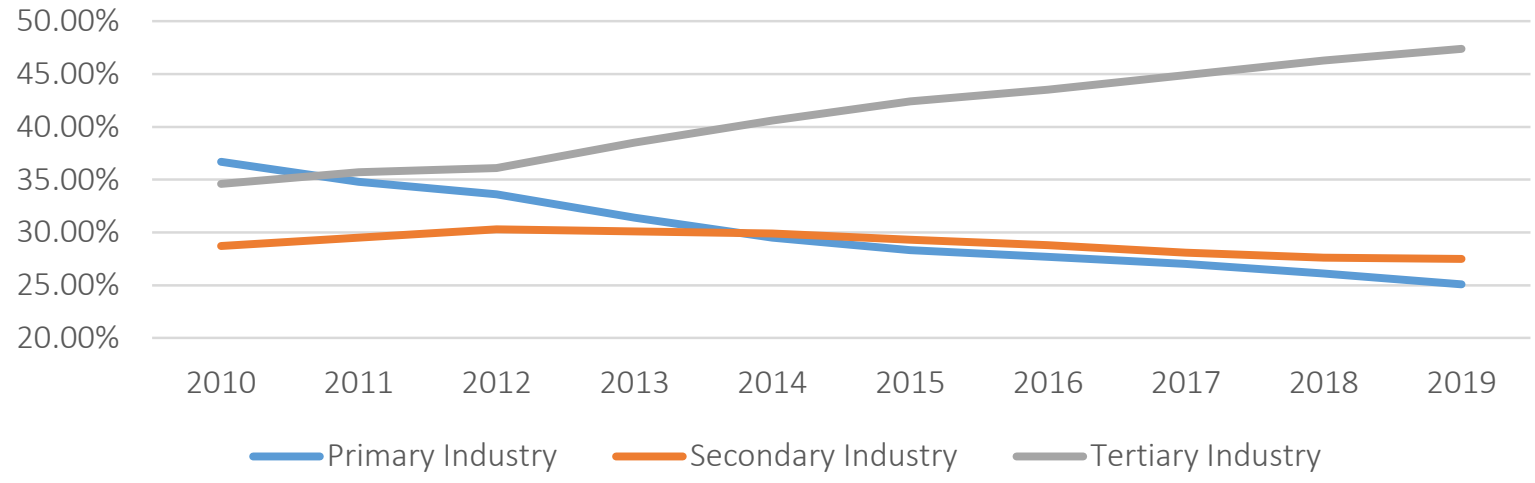

Figure 3. Dynamic changes of China's employment structure (2010-2019)

\subsection{Dynamic changes in employment structure}

The employment structure, also known as the social labor distribution structure, refers to the number, proportion, and interrelationship of the labor force in various sectors of the national economy, whose essence is labor allocation. Figure 3 shows the employment share of the labor force in each industry. The labor employment primary industry had declined relatively rapidly, and its share dropped from $36.7 \%$ in 2010 to $25.1 \%$ in 2019 . In contrast, the number of labor employment in the tertiary industry has increased faster, from $34.6 \%$ in 2010 to $47.4 \%$ in 2019 . However, the employment rate in the secondary industry fluctuated, 


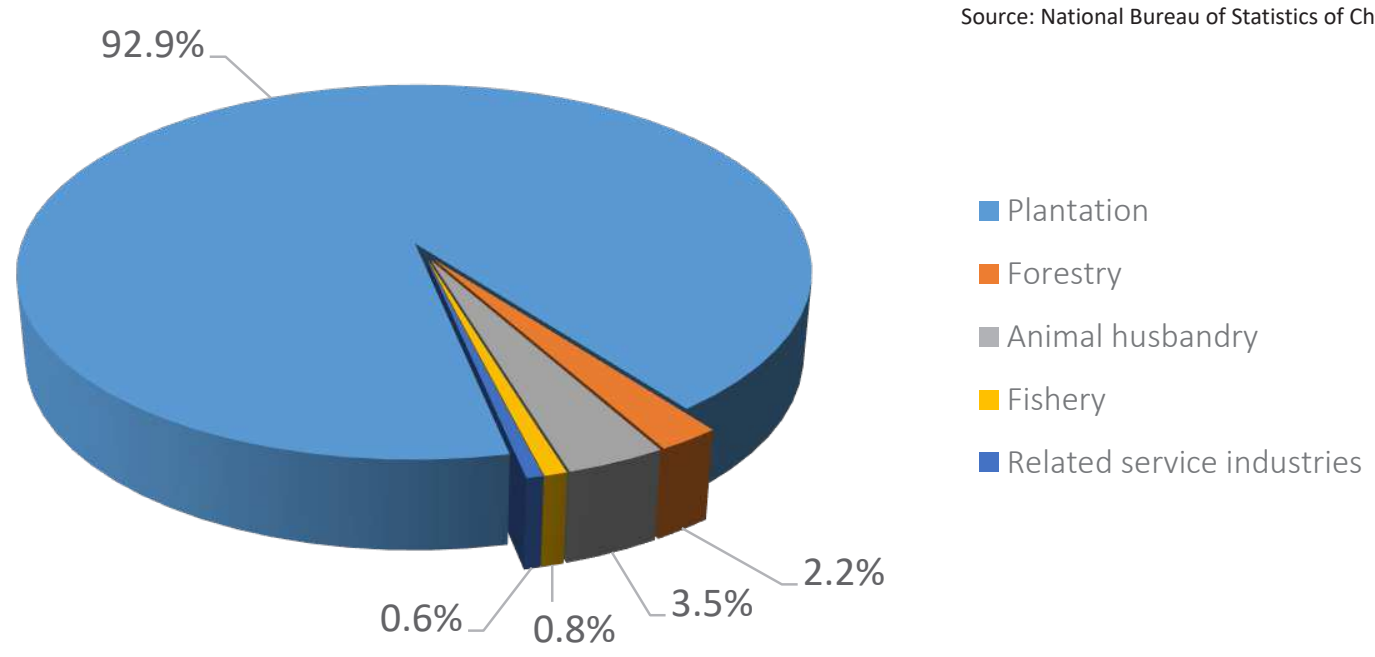

Figure 4. Composition of rural employees in the primary industry

but not to a great degree. The proportion of employment in 2010-2012 has increased to a certain extent, but it began to decline slightly after 2013 .

In China, the primary industry includes plantation, forestry, animal husbandry, fishery, and related service industries. Although the number of labors in the primary sector has decreased yearly since 2010, China is a large agricultural country. Agriculture is still the primary industry that farmers rely on for survival for most rural populations. Figure 4 is clearly showing that the proportion of the population engaged in farming in the primary sector was as high as $92.9 \%$.

\subsection{Correlation analysis}

The paper calculated the correlation coefficient $r$ through the CORREL function, among which the output value of three industries and the employment-population were variables. The positive and negative value of the correlation coefficient indicates the positive and negative directions of the correlation, and the absolute correlation coefficient value indicates the significance of the correlation. If the correlation coefficient's absolute value is above 0.8 , it is highly correlated. If the absolute value is between 0.5 and 0.8 , it is moderately correlated. If the absolute value is between 0.3 and 0.5 , it is weakly correlated. If the absolute value is below 0.3 , it means the correlation is very weak. By calculation, in the primary industry, the correlation coefficient was -0.98 , indicating that along with the increase in economic capacity of the pri- mary sector, the number of employed people in the primary industry is decreasing. The more the output value, the fewer the number of employees. There are two main reasons: the popularization of agricultural mechanization has increased labor productivity and reduced the number of laborers engaged in agricultural activities. The other is that the implementation of China's urbanization strategy has attracted many rural laborers. The correlation coefficient of the secondary industry was -0.58 , indicating that the increase in industrial output value did not increase the number of employees in this industry but decreased. The reason for this is that the development of capital-intensive and knowledge-intensive enterprises has reduced the labor absorption capacity of the secondary industry. The correlation coefficient of the tertiary industry was 0.98 , indicating that the increase in industrial output has promoted the increase in the employment-population of the industry. It shows that labor-intensive enterprises in the tertiary industry can attract many labor force employment.

\subsection{Employment elasticity analysis}

Employment elasticity is a descriptive measurement of the relationship between the economy and employment in a country or a region and reflects the ability of economic growth to absorb labor resources. Generally speaking, when the employment elasticity coefficient is greater than 0 , it means that the number of jobs can increase with economic growth; the more significant the value, the stronger the synchronous pulling effect, the 
Table 1. Employment elasticity coefficient of various industries in China (2010-2019)

Source: Calculated based on relevant data from the National Bureau of Statistics of China (2020).

\begin{tabular}{|c|c|c|c|c|}
\hline Year & $\begin{array}{l}\text { Total employment } \\
\text { elasticity coefficient }\end{array}$ & $\begin{array}{c}\text { Employment elasticity } \\
\text { coefficient of the primary } \\
\text { industry }\end{array}$ & $\begin{array}{l}\text { Employment elasticity } \\
\text { coefficient of the secondary } \\
\text { industry }\end{array}$ & $\begin{array}{l}\text { Employment elasticity } \\
\text { coefficient of the tertiary } \\
\text { industry }\end{array}$ \\
\hline 2010 & 0.004 & -0.198 & 0.024 & 0.017 \\
\hline 2011 & 0.004 & -0.211 & 0.020 & 0.028 \\
\hline 2012 & 0.006 & -0.191 & 0.040 & 0.014 \\
\hline 2013 & 0.005 & -0.406 & -0.004 & 0.059 \\
\hline 2014 & 0.005 & -0.532 & -0.005 & 0.053 \\
\hline 2015 & 0.004 & -0.405 & -0.100 & 0.038 \\
\hline 2016 & 0.003 & -0.179 & -0.024 & 0.022 \\
\hline 2017 & 0.000 & -0.282 & -0.015 & 0.023 \\
\hline 2018 & -0.001 & -0.259 & -0.013 & 0.021 \\
\hline 2019 & -0.002 & -0.142 & -0.004 & 0.018 \\
\hline
\end{tabular}

smaller the value, the weaker the synchronous pulling effect. When the employment elasticity coefficient is less than 0 , there is a "crowding out" and "sucking in" effect between the two. The larger the absolute value of the employment elasticity coefficient, the more significant the "crowding out" and "sucking in" effect between economy and employment. When the employment elasticity coefficient is 0 , the growth rate of employment is 0 . This shows that the increase or decrease of the output value of the industry is not related to the number of people employed in the industry. Since the number of employed workers in any industry is constantly changing, the possibility of this situation is minimal. In general, if the absolute value of the employment elasticity coefficient of an industry is close to 0 , it means that the development of the industry has little impact on the fluctuation of the employment-population.

Based on the relevant statistical data of the National Bureau of Statistics of China (2020), this paper used formula (1) to calculate the employment elasticity coefficients of various industries from 2010 to 2019. Table 1 shows the results.

Table 1 showed that the total employment elasticity coefficient was positive (except for 2018 and 2019), indicating that the increase in output was accompanied by an increase in employment. However, since the absolute value of the elasticity coefficient was nearly close to zero, the development of the three industries had little impact on the fluctuation of the employment-population. To analyze it in detail, the employment elasticity coefficient of the primary industry had been neg- ative over the years, and the absolute value of the elasticity coefficient even exceeded 0.4 from 2013 to 2015 , showing that the primary industry had a significant "extrusion" effect on employment. To be specific, as the production value of the primary industry increases, the number of employees in this industry has been in a state of negative growth, and the labor force continues to depart from the industry. The employment elasticity coefficient of the secondary industry showed relatively large fluctuations volatility. For example, from 2010 to 2012, the employment elasticity coefficient of the secondary industry was greater than 0 , showing that the industry had a specific stimulating effect on employment growth, and the production value of the secondary industry increased with the growth of employment. However, the absolute value of the employment elasticity coefficient was almost close to 0 , indicating that this stimulating effect was relatively weak. Since 2013, the employment elasticity coefficient has turned to be negative, and the role of the secondary industry's economic growth in stimulating employment growth has begun to disappear; instead, there was a slight "crowding out" effect. In contrast, the employment structure tended to parallel with the development of the industry in the tertiary industry. The employment elasticity coefficients in the tertiary industry were all greater than 0 , showing that the development of the tertiary industry had played a specific role in stimulating employment, but this promotion was not prominent. When the employment elasticity coefficient is close to 0 , the development of the industry has little effect on the fluctuation of the employed population. 


\subsection{Deviation coefficient of employment structure}

The employment structure deviation coefficient can quantitatively analyze the equilibrium. According to formula (2), the deviation coefficient of the employment structure industry can be calculated for years, as in Table 2. On the whole, the greater the absolute value of $D_{i}$, the greater the deviation, that is, more unbalanced. The smaller the absolute value, the smaller the deviation, that is, the more balanced. Specifically, when the industry employment structure deviation coefficient of $i$ is positive, the industrial output value composition percentage is ahead of employment. At this time, increased labor productivity caused the imbalance. When the employment structure deviation coefficient is negative, the composition percentage of the industrial output value lags behind that of employment. At this time, the imbalance is caused by reducing labor productivity. When the employment structure deviation coefficient is close to zero, it indicates that the employment structure and the industrial structure are balanced.

Table 2 and Figure 5 showed that the deviation coefficient of the employment structure of the primary industry was always negative, and the absolute value of the deviation coefficient was far from zero. The structural deviation of each year fluctuated between $-0.70 \%$ and $-0.75 \%$, indicating that the output value composition percentage of the primary industry lagged behind the employment composition percentage. At this time, the scale of the labor force stranded in the primary industry was relatively large, and the employment carrying capacity of the industry was relatively low. In particular, the absorption effect of the land on the labor force was gradually reduced, and the development of employment and industrial structures was not balanced. The structural deviation degree of the secondary industry was positive and fluctuated to some degree. It kept decreasing before 2016, had a brief recovery from 2017 to 2018, and decreased again in 2019. Nevertheless, the degree of structural deviation of the secondary industry remained high, always hovering around 0.4, unbalanced development still exists. The deviation degree of the employment structure of the tertiary industry had generally maintained a steady decline, indicating that the tertiary sector is relatively well balanced.

\section{DISCUSSION}

This study shows that there is a strong correlation between China's industrial structure and the employment structure of human resources during 2010-2019, which is consistent with the results of previous studies. As mentioned in the literature review, it is agreed that there is a relationship between the two and is believed that they are obviously correlated. Chen (2007) and Chen and Shi (2012) confirm this view. In terms of the degree of employment structure deviation, Wang (2010) pointed out that the structure deviation degree of the secondary industry was the largest from 1979 to 2008, and the structure deviation degree of the primary industry and the tertiary industry showed an increasing and decreasing development trend respectively. This paper further supports this finding. However, in terms of the absorptive capacity of the industrial economy of employment, the research results in this paper are different from those in previous studies. This

Table 2. Deviation coefficient of the employment structure in various industries in China (2010-2019)

Source: Calculated based on relevant data from the National Bureau of Statistics of China (2020).

\begin{tabular}{|c|c|c|c|c|c|c|c|c|c|c|c|}
\hline Industry & Year & 2010 & 2011 & 2012 & 2013 & 2014 & 2015 & 2016 & 2017 & 2018 & 2019 \\
\hline \multirow{3}{*}{$\begin{array}{l}\text { Primary } \\
\text { Industry }\end{array}$} & V & $9.33 \%$ & $9.18 \%$ & $9.11 \%$ & $8.94 \%$ & $8.64 \%$ & $8.39 \%$ & $8.06 \%$ & $7.46 \%$ & $7.04 \%$ & $7.11 \%$ \\
\hline & $E$ & $36.70 \%$ & $34.80 \%$ & $33.60 \%$ & $31.40 \%$ & $29.50 \%$ & $28.30 \%$ & $27.70 \%$ & $26.98 \%$ & $26.11 \%$ & $25.10 \%$ \\
\hline & D & -0.75 & -0.74 & -0.73 & -0.72 & -0.71 & -0.70 & -0.71 & -0.72 & -0.73 & -0.72 \\
\hline \multirow{3}{*}{$\begin{array}{l}\text { Secondary } \\
\text { Industry }\end{array}$} & V & $46.50 \%$ & $46.53 \%$ & $45.42 \%$ & $44.18 \%$ & $43.09 \%$ & $40.84 \%$ & $39.58 \%$ & $39.85 \%$ & $39.69 \%$ & $38.97 \%$ \\
\hline & $E$ & $28.70 \%$ & $29.50 \%$ & $30.30 \%$ & $30.10 \%$ & $29.90 \%$ & $29.30 \%$ & $28.80 \%$ & $28.11 \%$ & $27.57 \%$ & $27.50 \%$ \\
\hline & D & 0.62 & 0.58 & 0.50 & 0.47 & 0.44 & 0.39 & 0.37 & 0.42 & 0.44 & 0.42 \\
\hline \multirow{3}{*}{$\begin{array}{l}\text { Tertiary } \\
\text { Industry }\end{array}$} & $\mathrm{V}$ & $44.18 \%$ & $44.29 \%$ & $45.46 \%$ & $46.88 \%$ & $48.27 \%$ & $50.77 \%$ & $52.36 \%$ & $52.68 \%$ & $53.27 \%$ & $53.92 \%$ \\
\hline & $\mathrm{E}$ & $34.60 \%$ & $35.70 \%$ & $36.10 \%$ & $38.50 \%$ & $40.60 \%$ & $42.40 \%$ & $43.50 \%$ & $44.91 \%$ & $46.32 \%$ & $47.40 \%$ \\
\hline & D & 0.28 & 0.24 & 0.26 & 0.22 & 0.19 & 0.20 & 0.20 & 0.17 & 0.15 & 0.14 \\
\hline
\end{tabular}


Source: Calculated based on relevant data from the National Bureau of Statistics of China (2020).

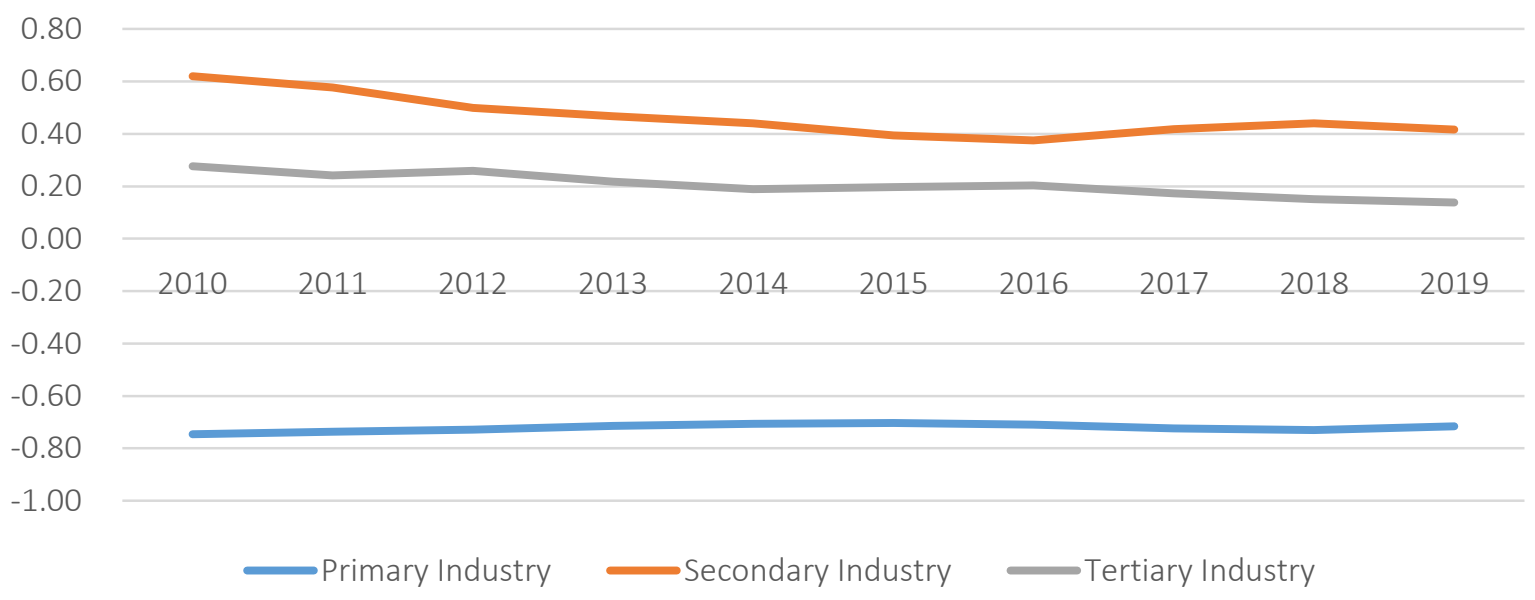

Figure 5. Trend chart of deviation coefficient of the employment structure in various industries in China (2010-2019)

paper analyzed the simultaneous pulling effect of industrial economic growth on employment using the employment elasticity coefficient. It was found that the employment elasticity coefficient of the secondary industry in China was primarily negative from 2010 to 2019, indicating that along with the increase in the output value of the secondary industry, the number of people employed in the secondary industry decreased instead. This result is contrary to the findings of Wang (2010) and Zhou et al. (2018). Wang (2010) shows that the employment elasticity coefficient of the secondary industry in China was mainly positive from 1979 to 2008 , and the increase in the output value of the secondary industry drove the increase in employment. This inconsistency of research results may be caused by the number of technology-intensive and capital-intensive enterprises in the secondary industry increasing in recent years, and the rela- tive labor productivity has increased significantly, so enterprises have begun to reduce their staff and increase their efficiency continuously. The demand for labor has been decreasing. Thus, the actual number of employees in the secondary industry is decreasing. It also has a specific relationship with the level of local economic development.

This study reinforces the view that the relationship between China's industrial structure and human resource employment structure is constantly and dynamically changing, showing different developmental characteristics at different historical periods. On the surface, some of the results contradict previous studies. However, this contradiction is consistent with the laws of economic development. This also provides some literature support for studying the relationship between the two.

\section{CONCLUSION}

This study aims to understand the relationship between China's industrial structure and human resources employment structure. Both employment elasticity coefficient analysis and industrial structure deviation analysis fully prove that China's industrial structure and employment structure strongly correlate. Their evolution process is basically in line with the general law of industrial structure development. The position of tertiary industry in the industrial system is steadily increasing.

However, specific analysis reveals that all three industries have different degrees of employment structure deviation, and the coordination between industrial structure and employment structure is poor. This phenomenon is mainly due to the inconsistency of the current labor market, and there is a capital substitution effect, but also the externalization of the low quality of the labor force. The results of this study also reveal the current employment in China. For example, the problem of invisible unem- 
ployment in the primary industry is more serious, and there is a demand for labor to transfer out; the structural contradiction in the secondary industry is prominent, and the supply of high-quality talents is insufficient; the jobs in the tertiary sector are saturated, and the pulling effect on employment is reduced, etc. It is hoped that this discovery can help the human resources employment department better formulate employment policies and achieve full labor force engagement.

The limitation of this study is that the selected panel data has a relatively short period. Only the data from 2010 to 2019 are fixed, which cannot reflect the dynamic change process of the relationship between the industrial and employment structures more effectively. Therefore, in the follow-up research, efforts should be made to make up for the deficiencies in this area and expand the data sources.

\section{AUTHOR CONTRIBUTIONS}

Conceptualization: Lijuan Cui, Viktoriia Medvid.

Data curation: Lijuan Cui.

Formal analysis: Lijuan Cui, Viktoriia Medvid.

Funding acquisition: Lijuan Cui, Viktoriia Medvid.

Investigation: Lijuan Cui.

Methodology: Lijuan Cui, Viktoriia Medvid.

Project administration: Lijuan Cui, Viktoriia Medvid.

Resources: Lijuan Cui, Viktoriia Medvid.

Software: Lijuan Cui.

Supervision: Viktoriia Medvid.

Validation: Lijuan Cui, Viktoriia Medvid.

Visualization: Lijuan Cui, Viktoriia Medvid.

Writing - original draft: Lijuan Cui.

Writing - review \& editing: Viktoriia Medvid.

\section{REFERENCES}

1. Cao, K. H., \& Birchenall, J. A. (2013). Agricultural Productivity, Structural Change, and Economic Growth in Post-reform China. Journal of Development Economics, 104, 165-180. https://doi. org/10.1016/j.jdeveco.2013.06.001

2. Chen, D. (2007). A study on the correlation between Industrial structure and employment structure in China. Industry and Technology Forum, 6(3), 24-26. (In Chinese). Retrieved from https:// kns.cnki.net/kcms/detail/detail.as px?dbcode $=$ CJFD\&dbname $=$ CJFD 2007\&filename=DAJJ200703003

3. Chen, W. M., \& Shi, L. (2012). An Analysis of the Interactive Relationship between Jiangsu's Industrial Structure and Employment Structure. Business Research, 5, 74-78. (In Chinese). https://doi.org/10.13902/j.cnki. syyj.2012.05.006
4. Cieślik, A., \& Ghodsi, M. (2015). Agglomeration externalities, market structure and employment growth in high-tech industries: Revisiting the evidence. Miscellanea Geographica, 19(3), 76-83. https://doi.org/10.1515/ mgrsd-2015-0007

5. Clark, C. (1940). The Conditions of Economic Progress. New York: Macmillan Company.

6. Dai, Z. M., Ding, F., \& Guo, L. (2015). Analysis of the degree of coordination between industrial changes and employment structure in the Yangtze River Delta urban agglomeration: data from 1994 to 2013. Economic Reform, 1, 64-68. (In Chinese). Retrieved from https://kns.cnki. net/kcms/detail/detail.aspx?dbcod $\mathrm{e}=$ CJFD \&dbname $=$ CJFDLAST20 1 5\&filename $=$ JJTG201501025
7. Deng, X. Z., Huang, J. K., Rozelle, S., \& Uchida, E. (2008). Growth, Population and Industrialization and Urban Land Expansion of China. Journal of Urban Economics, 63(1), 96-115. https:// doi.org/10.1016/j.jue.2006.12.006

8. Ding, Y., Lu, C. W., \& Lin, Y. (2018). Rethinking of farmer vocational education in transition period: connotation, predicament and countermeasures. Adult Education, 3, 46-50. (In Chinese). Retrieved from https://kns.cnki. net/kcms/detail/detail.aspx?dbcod $\mathrm{e}=$ CJFD\&dbname $=$ CJFDLAST 201 8\&filename $=$ CRJY201803012

9. Du, H. Z. (2016). An Analysis of the Differences in the Employment Structure of Rural Residents in Jiangsu Province. Tianjin Agricultural Sciences, 22(11), 88-94. (In Chinese). Retrieved from https://kns.cnki. 
net/kcms/detail/detail.aspx?dbcod $\mathrm{e}=\mathrm{CJFD} \& \mathrm{dbname}=$ CJFDLAST201 6\&filename $=$ TJNY201611021

10. Everyday Reading Club. (2021). Results of the seventh national census announced. (In Chinese). Retrieved from https://www.360kuai.com/ pc/91bd889894cbb21cd

11. Fan, Y. X., \& Meng, F. J. (2021). Study on the optimization path of industrial structure from the perspective of employment promotion. Journal of Inner Mongolia University of Finance and Economics, 19(5), 116121. (In Chinese). https:// doi.org/10.13895/j.cnki.jimufe.2021.05.027

12. Fernández-Macías, E. (2012). Patterns of Employment Expansion in Europe, 19952007. In E. Fernandez-Macias, J. Hurley, \& D. Storrie (Eds.), Transformation of the Employment Structure in the EU and USA, 1995-2007 (pp. 26-51). New York: St Martin's Press. https://doi. org/10.1057/9780230369818_3

13. Ge, P., Sun, W. K., \& Zhao, Z. (2021). Employment structure in China from 1990 to 2015. Journal of Economic Behavior \& Organization, 185, 168-190. https://doi. org/10.1016/j.jebo.2021.02.022

14. Geng, L. H. (2020). Development of rural human resources to promote rural economic development direction research. The Chinese Market, 30, 104105. (In Chinese). https:// doi.org/10.13939/j.cnki. zgsc.2020.30.104

15. Geng, Z. S. (2020). Outstanding problems and countermeasures of rural development under the background of rural revitalization. Rural Economy and Technology, 31(13), 256-258. (In Chinese). Retrieved from https://kns.cnki. net/kcms/detail/detail.aspx?dbcod $\mathrm{e}=$ CJFD\&dbname $=$ CJFDLAST202 0\&filename $=$ NCJI202013114

16. Han, S., \& Ji, S. Y. (2021). The path of vocational education serving rural human resources development in the new period. Exploration of Higher Vocational Education, 20(2), 53-57. (In
Chinese). Retrieved from https:// kns.cnki.net/kcms/detail/detail. aspx ?dbcode $=$ CJFD\&dbname $=$ CJFDLAST2021\&filename $=Y X$ ZY202102010

17. Hollanders, H., \& ter Weel, B. (2002). Technology, knowledge spillovers and changes in employment structure: evidence from six OECD countries. Labour Economics, 9(5), 579-599. https://doi.org/10.1016/S09275371(02)00056-8

18. Hong, M. Y. (2018). Urban and Rural Dual Land System: Logical Starting Point, Evolution and Future Reform. Economic Research Reference, 38, 31-41. (In Chinese). https://doi.org/10.16110/j.cnki. issn2095-3151.2018.38.005

19. Hou, H. J. (2020). Research on rural human resources development based on the background of rural revitalization strategy. Commercial Economy, 9, 111-113. (In Chinese). https://doi.org/10.19905/j.cnki. syjj1982.2020.09.039

20. Huang, H. W., Yang, Z. Y., \& Meng, F. J. (2018). The urbanrural income distribution effect of the coordinated development of industrial structure and employment structure: a theoretical analysis framework. Northern Economy, 5, 38-40. (In Chinese). Retrieved from https:// kns.cnki.net/kcms/detail/detail. aspx? dbcode $=$ CJFD\&dbname $=$ CJFDLAST2018\&filename $=\mathrm{BF}$ JJ201805012

21. Jin, W. D. (2010). The dynamic matching effect of the transformation of human capital and industrial structure: A review of employment, growth and income distribution. Economic Review, 6, 137-142. (In Chinese). https://doi.org/10.19361/j. er.2010.06.017

22. Jing, J. J. (2016). Study on the coordination between Industrial structure and employment structure in China. Economic Problems, 1, 60-65. (In Chinese). https://doi.org/10.16011/j.cnki. jjwt.2016.01.011

23. Katz, L. F., \& Murphy, K. M. (1992). Changes in Relative Wages,
1963-1987: Supply and Demand Factors. The Quarterly Journal of Economics, 107(1), 35-78. https:// doi.org/10.2307/2118323

24. Krumm, R., \& Strotmann, H. (2013). The Impact of Regional Location Factors on Job Creation, Job Destruction and Employment Growth in Manufacturing. Jahrbuch für Regionalwissenschaft, 33, 23-48. https://doi.org/10.1007/ s10037-012-0069-y

25. Kuznets, S. (1980). Modern Economic Growth: Rate, Structure and Spread. New Haven and London: Yale University Press.

26. Li, C. A., \& Li, Y. (2021). Study on the evolution of China's labor force structure and its influence. Journal of China Institute of Labor Relations, 35(5), 1-11. (In Chinese). Retrieved from https:// kns.cnki.net/kcms/detail/detail. aspx ? dbcode $=$ CJFD \&dbname $=$ CJFDLAST2021\&filename $=\mathrm{GH}$ LJ202105001

27. Li, J., Xu, X. G., Chen, L., \& Chen, C. B. (2010). Research on the Impact of Rural Labor Employment on Agriculture and Rural Economic Development in the "Twelfth Five-Year Plan" Period. Economic Research Reference, 45, 2-13. (In Chinese). https://doi.org/10.16110/j.cnki. issn2095-3151.2010.45.002

28. Li, X. K., Tan, X., \& Qi, X. (2015a).Comparative study on harmonious development of employment structure and industrial structure. Journal of Shanghai Business School, 16(5), 106-115. (In Chinese). Retrieved from https://kns.cnki.net/kcms/ detail/detail.aspx?dbcode $=$ CJFD\& dbname $=$ CJFDLAST2016\&filena me $=$ SHSS201505016

29. Li, X. Y., Xu, Y. Y., \& Wang, Y. Y. (2015b). China's industrial structure and employment structure coordination analysis. Journal of Shandong University of Finance and Economics, 27(3), 8493. (In Chinese). Retrieved from https://kns.cnki.net/kcms/detail/ detail.aspx?dbcode $=$ CJFD\&dbna $\mathrm{me}=\mathrm{CJFDLAST} 2015 \&$ filename $=\mathrm{S}$ DCY201503012

30. Li, Y. F., \& Gao, C. Y. (2008). Cointegration analysis of industrial 
structure and employment structure. Statistics and Decision, 4, 84-86. (In Chinese). Retrieved from https://kns.cnki.net/kcms/ detail/detail.aspx? dbcode $=$ CJFD\& dbname $=$ CJFD2008\&filename $=\mathrm{T}$ JC200804033

31. Liu, T. S., \& Zhang, Y. H. (2020). Urban and rural dual land system and its reform in the process of urbanization. Seek, 2 , 135-142. (In Chinese). https:// doi.org/10.16059/j.cnki.cn431008/c.2020.02.016

32. Ma, J. F. (2016). The role and action of government in cultivating new professional farmers. Vocational and Technical Education in China, 18, 64-68. (In Chinese). Retrieved from https:// kns.cnki.net/kcms/detail/detail. aspx $?$ dbcode $=C J F D \& d b n a m e=$ CJFDLAST2016\&filename $=\mathrm{ZO}$ NE201618012

33. National Bureau of Statistics of China. (2017). Main data bulletin of the third national agricultural census of China. (In Chinese). Retrieved from http://www.stats. gov.cn/tjsj/tjgb/nypcgb/qgnypcgb/201712/t20171215_1563599. html

34. National Bureau of Statistics of China. (2018). China Population and Employment Statistical Yearbook. Beijing: China Statistics Press. (In Chinese). Retrieved from https://www.chinayearbooks com/china-population-andemployment-statistics-yearbook-2018.html

35. National Bureau of Statistics of China. (2020). China Statistical Yearbook. Beijing: China Statistics Press. (In Chinese). Retrieved from https://www.chinayearbooks. com/china-statistical-yearbook-2020.html

36. Qin, Q., \& Fang, S. C. (2011). The relationship between industrial structure and employment structure in Chongqing city and policy recommendations. Agricultural Modernization Research, 32(6), 695-699. (In Chinese). Retrieved from https:// kns.cnki.net/kcms/detail/detail.as px? dbcode $=$ CJFD\&dbname $=$ CJFD 2011\&filename $=$ NXDH201106014
37. Rachwal, T. (2011).

Transformations of the Employment Structure as an Expression of the Transformation of Polish Industry Against the Background of the European Union. Bulletin of Geography: Socio-Economic Series, 15(15), 5-25. https://doi.org/10.2478/ v10089-011-0001-1

38. Ranis, G., \& Fei, C. H. (1961). A Theory of Economic Development. The American Economic Review, 51(4), 533-565. Retrieved from https://www.jstor.org/stable/1812785

39. Rural Social and Economic Investigation Department of National Bureau of Statistics of China. (2019). China Rural Statistical Yearbook. Beijing: China Statistics Press. (In Chinese).

40. Schumpeter, J.A. (1911).Theory of Economic Development. Cambridge: Harvard University Press.

41. Song, S.Y., \& Xu, B. (2015). A study on the interaction between industrial structure and employment structure and employment policies in China. Industrial Economics Review, 4, 28-43. (In Chinese). https:// doi.org/10.19313/j.cnki.cn101223/f.2015.04.003

42. Song, X. X., \& Shi, J. Z. (2021). Empirical study on the impact of industrial structure adjustment on employment in Hebei Province. Cooperative Economy and Technology, 20, 109-111. (In Chinese). https:// doi.org/10.13665/j.cnki.hzjjykj.2021.20.040

43. Sun, J., \& Yao, J.F. (2011). An Empirical Analysis of the Contribution of Industrial Transfer to Jiangsu's Regional Economic Development: Taking the North-South Joint Construction of Industrial Parks as an Example. Economic Geography, 31(03), 432436. (In Chinese). https:// doi.org/10.15957/j. cnki. jjdl.2011.03.014

44. Sun, Z., \& Hou, Y. L. (2019). How does industrial intelligentization reshape labor force employment structure. Chinese Industrial Economy, 5, 61-79. (In Chinese). https://doi.org/10.19581/j.cnki. ciejournal.2019.05.004

45. Tang, Z. X. (2019). Rural financial development, employment structure and farmers' income growth in Anhui Province: an empirical test based on data from 2003 to 2017. Journal of Anhui Business Vocational and Technical College, 2, 34-37. (In Chinese). https://doi.org/10.13685/j.cnki. abc.000405

46. Wang, Q. F. (2010). Research on the Coordinated Development of Chinese Industrial Structure and Employment Structure. Nanjing University of Aeronautics and Astronautics. (In Chinese) Retrieved from https://kns.cnki. net/kcms/detail/detail.aspx?dbcod $\mathrm{e}=\mathrm{CDFD} \& \mathrm{dbname}=\mathrm{CDFD} 1214 \&$ filename $=1011291625$. nh\&unipla tform $=\mathrm{NZKPT} \& \mathrm{v}=\mathrm{ETqP} 1 \mathrm{hDpx} 2$ K3mo1J86

47. Wei, P., Ren, A. R., \& Li, J. (2015). Research on the relationship between Industrial structure and employment structure in China - Based on coordination and impact perspective. Exploration of Economic Issues, 11, 54-62. (In Chinese). Retrieved from https:// kns.cnki.net/kcms/detail/detail. aspx ?dbcode $=\mathrm{CJFD} \& \mathrm{dbname}$ $=$ CJFDLAST2015\&filename $=$ JJ WS201511010

48. William, P. (2010). Political Arithmetic. Beijing: China Social Sciences Press.

49. Wu, P. L. (2015). The construction of modern agriculture has reached a new stage. Nanjing: Jiangsu People's Publishing House.

50. Wu, S. H. (2016). The impact of industrial structure changes on the economy and employment structure-taking developed countries as an example. Market Modernization, 6, 241 242. (In Chinese). https:// doi.org/10.14013/j.cnki.scxdh.2016.06.134

51. Xianmei, B. (2021). Difficulties and countermeasures of rural labor resource development. Farm staff, 18, 9-10. (In Chinese). Retrieved from https://kns.cnki. 
net/kcms/detail/detail.aspx?dbcod $\mathrm{e}=$ CJFD\&dbname $=$ CJFDLAST202 $1 \&$ filename $=$ NJCM202118005

52. Xu, B. (2014). The Interaction between China's Industrial Structure and Employment Structure and Employment Policy Research (Master's Thesis). Liaocheng University. (In Chinese). Retrieved from https://kns.cnki.net/kcms/detail/ detail.aspx?dbcode $=$ CMFD\&d bname $=$ CMFD201501\&filena me=1014049704.nh\&uniplatform

53. Zhang, C. (2016). A summary of the literature on the research on industry structure and employment structure connection. Journal of Huizhou University, 36(4), 42-46. (In Chinese). Retrieved from http://www.doc88. com/p-3032313188386.html

54. Zhang, K. S., \& Wang, Z. B. (2014). Imbalances in China's industrial and employment structures and their policy implications. Studies in Economics and Management,
8, 45-53. (In Chinese). https:// doi.org/10.13502/j.cnki.issn10007636.2014.08.007

55. Zhang, M. (2014). The relationship between employment structure and industrial structure in Hengyang. Industry and Technology Forum, 13(15), 30-31. (In Chinese). Retrieved from https://kns.cnki.net/kcms/detail/ detail.aspx? dbcode $=$ CJFD\&dbna me $=$ CJFDLAST2015\&filename $=\mathrm{C}$ YYT201415014

56. Zhao, J. M. (2019). The profound influence of developing rural vocational education on rural human resources. Adult Education in China, 22, 91-93. (In Chinese) Retrieved from https://kns.cnki. net/kcms/detail/detail.aspx?dbcod $\mathrm{e}=$ CJFD \&dbname $=$ CJFDLAST202 0\&filename $=$ ZCRY201922024

57. Zhou, B., \& Xu, A. D. (2008). The construction of the mechanism between the industrial structure and the employment structure -
Based on the empirical study of the relationship between the industrial structure and the employment structure in China. Soft Science, 7, 84-87. (In Chinese). Retrieved from https://kns.cnki. net/kcms/detail/detail.aspx?dbcod $\mathrm{e}=\mathrm{CJFD} \& \mathrm{dbname}=$ CJFD2008\&file name $=$ XUXI200807020

58. Zhou, Y. Q., Guo, C. L., Sun, W. T., \& Cao, J. (2018). Study on the deviation between employment structure and industrial structure in Jiangning District. Chinese Collective Economy, 36, 26-27. (In Chinese). Retrieved from https:// kns.cnki.net/kcms/detail/detail. aspx ?dbcode $=$ CJFD\&dbname $=$ CJFDLAST2018\&filename $=\mathrm{ZJ}$ TG201836012

59. Zimmermann, K. F. (1991). The employment consequences of technological advance, demand and labor costs in 16 German industries. Empirical Economics, 2, 253-266. https://doi.org/10.1007/ BF01193494 